\title{
Differences Between Oral Health According to Water Intake Using the Data from South Korea's 7-Year National Health and Nutrition Survey
}

Yu-Rin Kim ( $\nabla$ dbfls1712@hanmail.net )

Silla University

\section{Research Article}

Keywords: habits, oral health, periodontal disease, self-care, water

Posted Date: March 9th, 2021

DOI: https://doi.org/10.21203/rs.3.rs-244499/v1

License: (c) (1) This work is licensed under a Creative Commons Attribution 4.0 International License.

Read Full License 


\section{Abstract}

Background: Proper moisture is an essential condition for maintaining the homeostasis of the body, enhancing immunity, and preventing constipation, and it is an indispensable substance for maintaining human life and health. The bacteria that cause oral disease are affected by water intake. Therefore, this study aims to compare the relationship between dental caries and periodontal disease according to the amount of water drank per day.

Methods: Among the data of the National Health and Nutrition Survey conducted annually by the Korea Centers for Disease Control and Prevention, the data for 7 years (2010-2017) were analyzed. Out of a total of 64,758 people, 134 people in the ' $<1$ cup' group, 27,223 people in the ' $1-4$ cups' group, and 25,877 people in the ' 5 cups $\leqq$ ' group were selected as subjects.

Results: As a result, the prevalence of periodontal disease increased by 1.018 times, the prevalence of dental caries increased by 1.032 times, and the experience of dental caries increased by 1.075 times each time a person drank one less cup of water per day. Even in model 2, for which age and gender were adjusted, there was a significant effect. In addition, there was significant impact in Model 3, which adjusted oral health behavior, except for permanent caries prevalence. Based on the above results, oral health behaviors and state were positive in those who consumed a lot of water per day.

Conclusions: Therefore, it is considered that the government's active promotion of water intake recommendations and policies should be prepared so that water intake can become a habit to improve oral health.

\section{Background}

Water accounts for $60 \%$ of an adult's weight. About $70 \%$ of the water is distributed within the cells, while the rest is distributed outside the cells in the form of epilepsy, plasma, lymphatic fluid, and other body fluids [1]. This water transports nutrients and waste products as major components of blood, and acts as a solvent for various biochemical reactions in the body [2]. In addition, it controls body temperature in the form of sweat, digests food as a component of various digestive fluids, and acts as a lubricant to smoothly move joints and internal organs in the form of synovial fluid and mucus [3,4]. Water also plays a role in protecting the internal organs and fetus in the cerebrospinal fluid and amniotic fluid of pregnant women. Therefore, proper moisture is an essential condition for maintaining the homeostasis of the body, enhancing immunity, and preventing constipation, and it is an indispensable substance for maintaining human life and health [5]. However, if the balance of water is broken or the body lacks too much water, the human body exhibits a dehydration reaction. If $2 \%$ of the total amount of water in the body decreases, we feel thirst, and if it decreases by $2-4 \%$, muscle fatigue is easily induced, and motor and cognitive functions are reduced. If more than $10 \%$ is lost, fatal organ damage and clinical shock can result and put life at risk, whereas a loss of more than $15-20 \%$ can worsen dehydration, thereby leading to death [6,7]. Without water, humans can only survive for $2-4$ days $[5,8,9]$; therefore, maintaining adequate moisture is 
very important. Since $5-10 \%$ of water must be exchanged every day, the amount of water required per day depends on body weight, temperature, activity, and body calorie consumption [10-13]. As such, the total amount of water intake that must be supplied to our body from the outside is $1-3 \mathrm{~L}$, thereby indicating a wide range $[14,15]$. Although it is recommended to consume $30 \mathrm{~mL}$ per $\mathrm{kg}$ of body weight [16] or $1 \mathrm{~mL}$ of water per kilocalorie [13], the amount of water that adults consume through water or beverages per day is reported as an average of $2 \mathrm{~L}$ [17]. Moreover, as the age increases, the intake of water decreases, thus leading to exposure to many diseases [18]. Lack of water can cause not only systemic problems, but also various health-related symptoms in the oral cavity, such as dry mouth, burning in the mouth due to thirst, or low saliva secretion, unlike ordinary people. If these symptoms persist, it can become an environment that causes oral disease [19].

Dental diseases are largely classified into dental caries and periodontal diseases, both of which are caused by microbial infection. Among more than 500 kinds of bacteria present in the oral cavity, the microbe that is most closely related to dental caries is Streptococcus mutans (S. mutans), a decisive causative agent that induces tooth decay by damaging the hard structure of the teeth [20-22]. Also, Prevotella intermedia ( $P$. intermedia), one of the major pathogens of periodontal disease, is known to be a powerful causative agent of adult periodontitis, pregnancy gingivitis, and ulcerative gingivitis, and it has been reported to be found in oral lesions $[23,24]$. These bacteria are affected by the amount of water intake. In particular, $P$. intermedia among oral microbes decreased as the amount of water intake increased [25]. In the study of Hong [26], it was reported that less $P$. intermedia causing periodontal disease was detected in the group drinking 3 to 4 glasses of water per day, and in the study of Jung et al [25], it was reported that dental caries-causing $S$. mutans was detected in the group with the least water in-take. However, these differences were not significant results and need to be re-confirmed. Therefore, it is necessary to check the relationship between dental caries and periodontal disease according to the amount of water drank per day. Until now, most studies have been conducted on the relationship between water intake and systemic diseases [3-9], and on water intake relationships in elderly [18, 25].

Furthermore, there are almost no studies on the relationship between oral health behavior and oral health state in all age groups. Therefore, this study aims to compare demographic characteristics, oral health behaviors, and oral health state according to the amount of water intake by using the 7-year data of the National Health and Nutrition Survey, which represents the Korean people, and to identify the substantial impact of water intake on periodontal diseases and dental caries in order to use the results as fundamental data to confirm the importance of water intake.

\section{Methods}

\section{Study Subjects}

Among the data of the National Health and Nutrition Survey conducted annually by the Korea Centers for Disease Control and Prevention, the data for 7 years (2010-2017) were analyzed. Of the total 64,758 people, 53,234 were selected, excluding those who taking medicine, people with systemic diseases and 
smokers. Depending on the intake of water, 134 people in the ' $<1$ cup' group, 27,223 people in the ' $1-4$ cups' group, and 25,877 people in the ' 5 cups $\leqq$ ' group were classified. There are no other ingredients added to the water, and the standard for 1 cup is $200 \mathrm{ml}$. The National Health and Nutrition Survey is a government-designated statistics based on Article 17 of the Statistics Act (approval no. 117002). In the $5^{\text {th }}$ round, the $1^{\text {st }}$ year survey is 2010-02CON-21-C, $2^{\text {nd }}$ year survey, 2013-12EXP-03-5C, and $3^{\text {rd }}$ year survey, 2012-01EXP-01-2C. In the $6^{\text {th }}$ round, the $1^{\text {st }}$ year survey is $2013-07 C 0 N-03-4 C$ and the $2^{\text {nd }}$ year survey is 2013-12EXP-03-5C. From the $3^{\text {rd }}$ year, it was conducted without deliberation by the Research Ethics Review Committee, as it corresponds to the research conducted by the State for public welfare directly pursuant to Subparagraph 1 of Article 2 (2).

\section{Data Collection}

\subsection{Demographic characteristics}

The survey year, gender, age, marriage, education, economy, and income were checked through the health survey of the National Health and Nutrition Survey. Economy was classified into currently employed and unemployed, and income was classified into 'low', 'middle-low', 'middle', 'middle-high', and 'high'.

\subsection{Oral health behavior}

For oral health behavior, toothbrushing timing consisted of 9 items, and the use of oral health products consisted of 5 items, with 1 for yes and 0 for no. The dental treatment consisted of 9 items, with 1 for the case of getting treatment and 0 for the case of not getting treatment.

\subsection{Oral health status}

For oral health status, chewing inconvenience and experience in toothache were checked, with 1 for yes and 0 for no. Speech problem and chewing problem were measured on a 5-point scale, and the higher the score, the less serious the problem. Self oral health consciousness was measured on a 5-point scale, and the lower the score, the better. Dental caries and periodontal disease ware directly examined by a public health dentist in the province at the mobile examination center. The periodontal disease was recorded as having periodontal disease if the periodontal pocket is more than $3 \mathrm{~mm}$ deep using probe. Permanent tooth caries and experience of permanent tooth caries were recorded by checking tooth caries using explorer. The presence of the disease was marked as 1 , and the absence of the disease was marked as 0 .

\section{Statistical Analyses}

Data analysis was conducted by using IBM SPSS ver. 21.0 (IBM Co., Armonk, NY, USA), and complex sampling analysis with stratification variables, colony variables, and weights assigned was applied to all 
analyses. The comparison of demographic characteristics and oral health behaviors according to 134 people in the '< 1 cup' group, 27,223 people in the ' $1-4$ cups' group, and 25,877 people in the ' 5 cups $\leqq$ ' group was conducted by using a complex sample chi-squared test. Logistic regression analysis and linear regression analysis were performed in order to determine the effect of daily water intake on oral health state, and 'Don't Know', 'Not Applicable', and 'Missing Values' in 8, 9, 88, and 99 were all excluded. The number of subjects in all tables was presented with an unweighted frequency, and the significance level of the statistical test was set to 0.05 .

\section{Results}

The ratio of the '< 1 cup' group was highest in 2012, and the ratio of the ' $1-4$ cups' group was highest in 2014. The ratio of the ' 5 cups $\leq$ ' group was highest in 2017. In the ' $<1$ cup' group the ratio of '21-40 years old' was higher, and in the ' $1-4$ cups' group and ' 5 cups $\leq$ ' group the ratio of ' $41-60$ years old' was higher. In the '< 1 cup' group and the ' $1-4$ cups' group, the ratio of women was higher than that of men, and in the ' 5 cups $\leq$ ' group, the ratio of men was higher than that of women. As for marriage, the ratio of married people was higher in all groups. In the '< 1 cup' group, middle-low income was highest. In the ' $1-4$ cups' group and the ' $5 \mathrm{cps} \leq$ ' group, low income was highest. As for education, in the '< 1 cup' group, university graduate was highest, and in the ' $1-4$ cups' group, elementary school graduate was highest. In the ' 5 cups $\leq$ ' group, high school graduate was highest. In terms of economic activities, employed was higher than currently unemployed regardless of the group. There were significant differences in all items of demographic characteristics (Table 1) $(p<0.05)$. 
Table 1

Demographic characteristics according to daily water intake N (\%)

\begin{tabular}{|c|c|c|c|c|c|}
\hline & & $\begin{array}{l}<1 \text { cup }(\mathrm{N}= \\
134)\end{array}$ & $\begin{array}{l}1-4 \text { cups }(N= \\
27,223)\end{array}$ & $\begin{array}{l}5 \text { cups } \leqq(N= \\
25,877)\end{array}$ & p \\
\hline \multirow[t]{8}{*}{ Year } & 2010 & $24(16.5)$ & $3,690(11.7)$ & $3,644(12.5)$ & 0.000 \\
\hline & 2011 & 23 (12.9) & $3,577(12.1)$ & $3,478(12.5)$ & \\
\hline & 2012 & $25(17.8)$ & $3,561(12.8)$ & $3,020(12.0)$ & \\
\hline & 2013 & 19 (14.6) & $3,488(13.0)$ & 3,095 (11.9) & \\
\hline & 2014 & $18(15.2)$ & $3,347(13.2)$ & 2,897 (11.9) & \\
\hline & 2015 & $10(9.7)$ & $3,063(12.5)$ & $3,029(12.7)$ & \\
\hline & 2016 & $6(6.0)$ & $3,300(12.7)$ & $3,267(12.9)$ & \\
\hline & 2017 & $9(7.3)$ & $3,197(12.1)$ & 3,447 (13.7) & \\
\hline \multirow[t]{4}{*}{ Age } & $\leqq 20$ & $21(15.7)$ & 7879 (26.1) & $4620(16.0)$ & 0.000 \\
\hline & $21-40$ & 34 (38.2) & $5048(26.2)$ & $6370(17.7)$ & \\
\hline & $41-60$ & $35(27.0)$ & $6758(28.8)$ & $8374(35.0)$ & \\
\hline & $61 \leqq$ & $44(19.1)$ & 7538 (18.8) & $6513(15.1)$ & \\
\hline \multirow[t]{2}{*}{ Gender } & Male & $57(46.0)$ & $10,189(42.0)$ & $13,060(58.2)$ & 0.000 \\
\hline & Female & $77(54.0)$ & $17,034(58.0)$ & $12,817(41.8)$ & \\
\hline \multirow[t]{2}{*}{ Married } & Single & $42(42.7)$ & $9,910(39.3)$ & $7,461(34.0)$ & 0.000 \\
\hline & Married & $92(57.3)$ & $17,271(60.7)$ & $18,389(66.0)$ & \\
\hline \multirow[t]{5}{*}{ Income } & Low & $23(20.4)$ & $5,424(21.2)$ & $4,932(20.3)$ & 0.024 \\
\hline & Middle-low & $34(25.7)$ & $5,567(20.7)$ & $5,082(20.1)$ & \\
\hline & Middle & 25 (17.5) & $5,358(19.7)$ & $5,263(20.1)$ & \\
\hline & Middle-high & 27 (18.5) & $5,484(19.8)$ & $5,133(19.6)$ & \\
\hline & High & $22(17.9)$ & $5,170(18.7)$ & $5,290(19.9)$ & \\
\hline \multirow[t]{4}{*}{ Education } & $\begin{array}{l}\text { Elementary } \\
\text { school }\end{array}$ & 37 (19.9) & 12,089 (35.8) & $7,620(21.5)$ & 0.000 \\
\hline & Middle school & $17(15.0)$ & $2,666(11.1)$ & $3,023(12.0)$ & \\
\hline & High school & $25(25.6)$ & $5,554(26.5)$ & $7,320(34.6)$ & \\
\hline & University & $43(39.5)$ & $5,612(26.6)$ & 6,767 (31.9) & \\
\hline Economic & Employed & 65 (61.2) & $10,041(55.2)$ & $12,653(63.5)$ & 0.000 \\
\hline
\end{tabular}




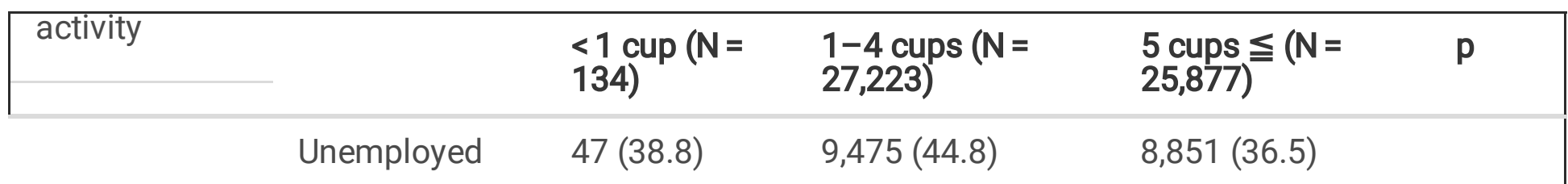

*By complex sample chi-square test, $p<0.05$

In terms of toothbrushing, brushing before dinner and before going to bed was highest in the ' $<1$ cup' group, and all items except for this were highest in the ' 5 cups $\leq$ ' group. There were significant differences in all items except for brushing before lunch and brushing before going to bed. As for the use of oral health products, the use of electric toothbrushes was highest in the ' $<1$ cup' group, and all items except for this were highest in the ' 5 cups $\leq$ ' group, and there were significant differences in all items. In dental treatment, simple caries treatment, surgical treatment, trauma treatment, and prosthetic treatment were highest in the '< 1 cup' group, and all items except for this were highest in the ' 5 cups $\leq$ ' group. There were significant differences in all items except oral examination, simple caries treatment, trauma treatment, and prosthetic treatment (Table 2) $(p<0.05)$. 
Table 2

Oral health behavior according to daily water intake $\mathrm{N}(\%)$

\begin{tabular}{|c|c|c|c|c|c|}
\hline & & $<1$ cup & $1-4$ cups & 5 cups $\leqq$ & $\mathbf{p}$ \\
\hline \multirow[t]{9}{*}{ Toothbrushing } & $\begin{array}{l}\text { I brushed my teeth yesterday. }(\mathrm{N}= \\
50,489)\end{array}$ & $\begin{array}{l}119 \\
(98.2)\end{array}$ & $\begin{array}{l}25,635 \\
(98.0)\end{array}$ & $\begin{array}{l}24,735 \\
(98.9)\end{array}$ & 0.000 \\
\hline & $\begin{array}{l}\text { I brushed my teeth before breakfast. } \\
(\mathrm{N}=14,206)\end{array}$ & $\begin{array}{l}35 \\
(31.2)\end{array}$ & $\begin{array}{l}6,698 \\
(29.2)\end{array}$ & $\begin{array}{l}7,473 \\
(32.8)\end{array}$ & 0.000 \\
\hline & $\begin{array}{l}\text { I brushed my teeth after breakfast. }(\mathrm{N} \\
=17,358)\end{array}$ & $\begin{array}{l}74 \\
(61.2)\end{array}$ & $\begin{array}{l}17,637 \\
(65.9)\end{array}$ & $\begin{array}{l}17,358 \\
(66.9)\end{array}$ & 0.037 \\
\hline & $\begin{array}{l}\text { I brushed my teeth before lunch. }(\mathrm{N}= \\
650)\end{array}$ & $2(1.3)$ & $286(1.2)$ & $362(1.4)$ & 0.103 \\
\hline & $\begin{array}{l}\text { I brushed my teeth after lunch. }(\mathrm{N}= \\
22,915)\end{array}$ & $\begin{array}{l}54 \\
(46.3)\end{array}$ & $\begin{array}{l}11,373 \\
(45.1)\end{array}$ & $\begin{array}{l}11,488 \\
(47.5)\end{array}$ & 0.000 \\
\hline & $\begin{array}{l}\text { I brushed my teeth before dinner. }(\mathrm{N}= \\
1,143)\end{array}$ & $4(3.6)$ & $490(2.1)$ & $649(2.8)$ & 0.000 \\
\hline & $\begin{array}{l}\text { I brushed my teeth after dinner. }(\mathrm{N}= \\
30,042)\end{array}$ & $\begin{array}{l}59 \\
(49.5)\end{array}$ & $\begin{array}{l}14,533 \\
(56.0)\end{array}$ & $\begin{array}{l}15,450 \\
(61.5)\end{array}$ & 0.000 \\
\hline & $\begin{array}{l}\text { I brushed my teeth after a snack. }(\mathrm{N}= \\
1,394)\end{array}$ & $1(0.8)$ & $624(2.5)$ & $769(3.0)$ & 0.000 \\
\hline & $\begin{array}{l}\text { I brushed my teeth before going to } \\
\text { bed. }(\mathrm{N}=20,841)\end{array}$ & $\begin{array}{l}52 \\
(45.0)\end{array}$ & $\begin{array}{l}10,696 \\
(44.2)\end{array}$ & $\begin{array}{l}10,093 \\
(43.6)\end{array}$ & 0.493 \\
\hline \multirow[t]{5}{*}{$\begin{array}{l}\text { Oral health } \\
\text { products }\end{array}$} & $\begin{array}{l}\text { Use of oral health products }(\mathrm{N}= \\
2,953)\end{array}$ & $\begin{array}{l}7 \\
(18.7)\end{array}$ & $\begin{array}{l}1,292 \\
(22.8)\end{array}$ & $\begin{array}{l}1,654 \\
(25.0)\end{array}$ & 0.041 \\
\hline & Use of floss $(N=7,855)$ & $\begin{array}{l}16 \\
(24.0)\end{array}$ & $\begin{array}{l}3,536 \\
(21.6)\end{array}$ & $\begin{array}{l}4,303 \\
(24.2)\end{array}$ & 0.000 \\
\hline & Use of interdental brush $(\mathrm{N}=7,026)$ & $8(6.9)$ & $\begin{array}{l}3,095 \\
(18.1)\end{array}$ & $\begin{array}{l}3,923 \\
(21.5)\end{array}$ & 0.000 \\
\hline & Use of mouthwash $(\mathrm{N}=6,931)$ & $\begin{array}{l}11 \\
(12.6)\end{array}$ & $\begin{array}{l}3,008 \\
(17.9)\end{array}$ & $\begin{array}{l}3,912 \\
(21.2)\end{array}$ & 0.000 \\
\hline & Use of electric toothbrush $(\mathrm{N}=1,938)$ & $\begin{array}{l}9 \\
(10.8)\end{array}$ & $862(5.2)$ & $\begin{array}{l}1,067 \\
(5.9)\end{array}$ & 0.004 \\
\hline \multirow{4}{*}{$\begin{array}{l}\text { Dental } \\
\text { treatment } \\
\text { (within the last } \\
\text { year) }\end{array}$} & I went to the dentist. $(\mathrm{N}=21,320)$ & $\begin{array}{l}44 \\
(39.8)\end{array}$ & $\begin{array}{l}10,685 \\
(40.9)\end{array}$ & $\begin{array}{l}10,591 \\
(42.1)\end{array}$ & 0.041 \\
\hline & $\begin{array}{l}\text { I had an oral examination. }(\mathrm{N}= \\
15,681)\end{array}$ & $\begin{array}{l}27 \\
(65.2)\end{array}$ & $\begin{array}{l}7,852 \\
(73.3)\end{array}$ & $\begin{array}{l}7,802 \\
(73.9)\end{array}$ & 0.343 \\
\hline & $\begin{array}{l}\text { I had periodontal treatment. }(\mathrm{N}= \\
3,831)\end{array}$ & $5(8.5)$ & $\begin{array}{l}1,693 \\
(15.7)\end{array}$ & $\begin{array}{l}2,133 \\
(19.3)\end{array}$ & 0.000 \\
\hline & $\begin{array}{l}\text { I had simple caries treatment. }(\mathrm{N}= \\
6,495)\end{array}$ & $\begin{array}{l}13 \\
(36.7)\end{array}$ & $\begin{array}{l}3,345 \\
(31.6)\end{array}$ & $\begin{array}{l}3,137 \\
(30.4)\end{array}$ & 0.248 \\
\hline
\end{tabular}




\begin{tabular}{|llllll|}
\hline & $<1$ cup & $\mathbf{1 - 4}$ cups & $\mathbf{5}$ cups $\leqq$ & $\mathbf{p}$ \\
\hline I had pulp treatment. $(\mathrm{N}=3,724)$ & 5 & 1,763 & 1,956 & 0.005 \\
& $(15.2)$ & $(16.8)$ & $(19.1)$ & \\
\cline { 2 - 6 } & I had oral health care. $(\mathrm{N}=8,057)$ & 12 & 3,760 & 4,285 & 0.000 \\
& $(33.2)$ & $(37.5)$ & $(42.9)$ & \\
\hline I had surgical treatment. $(\mathrm{N}=2,607)$ & 5 & 1,201 & 1,401 & 0.001 \\
& $(16.9)$ & $(11.7)$ & $(13.6)$ & \\
\hline I had trauma treatment. $(\mathrm{N}=458)$ & $1(2.7)$ & $226(2.3)$ & $231(2.4)$ & 0.935 \\
\hline I had prosthetic treatment. $(\mathrm{N}=4,427)$ & 12 & 2,158 & 2,257 & 0.265 \\
\hline & $(20.2)$ & $(18.3)$ & $(19.3)$ & \\
\hline
\end{tabular}

Chewing inconvenience was highest in the ' $1-4$ cups' group, and the experience in toothache was highest in the ' $<1$ cup' group. It was confirmed that speech and chewing problems were less in the ' 5 cups $\leq$ ' group, and self oral health consciousness was worst in the ' $<1$ cup' group. There were significant differences in all items. In addition, the prevalence of periodontal disease increased by 1.018 times, the prevalence of dental caries increased by 1.032 times, and the experience of dental caries increased by 1.075 times each time a person drank one less cup of water per day. Even in model 2, for which age and gender were adjusted, there was a significant effect. In addition, there was significant impact in Model 3 , which adjusted oral health behavior, except for permanent caries prevalence (Table 3$)(p<0.05)$. 
Table 3

Oral health status according to daily water intake N(\%)

\begin{tabular}{|c|c|c|c|c|c|}
\hline & & $<1$ cup & $\begin{array}{l}1-4 \\
\text { cups }\end{array}$ & 5 cups $\leqq$ & $\mathbf{p}$ \\
\hline \multirow{5}{*}{$\begin{array}{l}\text { Oral } \\
\text { health } \\
\text { status }\end{array}$} & $\begin{array}{l}\text { Chewing inconvenience }(\mathrm{N} \\
=10,180)\end{array}$ & $22(21.2)$ & $\begin{array}{l}5,148 \\
(22.8)\end{array}$ & $5,010(20.5)$ & 0.000 \\
\hline & $\begin{array}{l}\text { Experience in toothache }(\mathrm{N} \\
=11,254)\end{array}$ & $37(35.1)$ & $\begin{array}{l}5,551 \\
(30.4)\end{array}$ & $5,666(32.9)$ & 0.000 \\
\hline & ${ }^{\dagger}$ Speech problem & $4.26 \pm 0.01$ & $\begin{array}{l}4.33 \pm \\
0.01\end{array}$ & $4.41 \pm 0.01$ & 0.000 \\
\hline & ${ }^{\dagger}$ Chewing problem & $3.74 \pm 0.13$ & $\begin{array}{l}3.70 \pm \\
0.01\end{array}$ & $3.80 \pm 0.01$ & 0.000 \\
\hline & $\begin{array}{l}{ }^{\dagger} \text { Self oral health } \\
\text { consciousness }\end{array}$ & $3.34 \pm 0.10$ & $\begin{array}{l}3.28 \pm \\
0.01\end{array}$ & $3.31 \pm 0.01$ & 0.022 \\
\hline \multirow[t]{2}{*}{$\begin{array}{l}\text { "Oral } \\
\text { disease }\end{array}$} & $\begin{array}{l}\text { Prevalence of periodontal } \\
\text { disease }\end{array}$ & \multicolumn{2}{|l|}{$\begin{array}{l}\text { Permanent caries } \\
\text { prevalence }\end{array}$} & \multicolumn{2}{|l|}{$\begin{array}{l}\text { Permanent caries } \\
\text { experience }\end{array}$} \\
\hline & OR $(95 \% \mathrm{Cl})$ & OR $(95 \% \mathrm{Cl})$ & $\mathrm{p}$ & OR $(95 \% \mathrm{Cl})$ & $\mathrm{p}$ \\
\hline Model 1 & $\begin{array}{l}1.018(1.006 \sim \\
1.029)\end{array}$ & $\begin{array}{l}1.032(1.023 \sim \\
1.041)\end{array}$ & 0.000 & $\begin{array}{l}1.075(1.062 \sim \\
1.089)\end{array}$ & 0.000 \\
\hline Model 2 & $\begin{array}{l}1.018(1.006 \sim \\
1.029)\end{array}$ & $\begin{array}{l}1.022(1.013 \sim \\
1.032)\end{array}$ & 0.000 & $\begin{array}{l}1.060(1.046 \sim \\
1.073)\end{array}$ & 0.000 \\
\hline Model 3 & $\begin{array}{l}1.097(1.017 \sim \\
1.184)\end{array}$ & $\begin{array}{l}1.001(0.970 \sim \\
1.033)\end{array}$ & 0.947 & $\begin{array}{l}0.952(0.911 \sim \\
0.996)\end{array}$ & 0.032 \\
\hline
\end{tabular}

\section{Discussion}

As interest in immunity increases following the COVID-19 pandemic, interest in the effect of water intake on immune function and systemic diseases is growing [27]. Recently, it has been suggested that mild dehydration can lead to changes in various cognitive functions, such as concentration, arousal, and short-term memory [28]. On the other hand, Benton [29] argued that there are very few studies on the effect of dehydration on cognitive function, and confounding factors such as fatigue and body temperature related to dehydration are not well controlled, thereby making it difficult to draw a definite conclusion. While studies on water, systemic diseases, and mental disorders continue, studies confirming the relationship between water and oral disease are mostly those related to bacteria [25] and those limited to the elderly $[18,25]$. For this reason, it is necessary to expand these studies. Therefore, this study expanded and investigated subjects by using the data from the National Health and Nutrition Survey 
representing Korea, and analyzed the relationship between water and oral disease through the data from 2010 to 2017.

Women's water intake was lower than that of men, which is the same result as in the studies that were conducted in the US and Canada [30-32], and it is considered to be a complex result by female hormones [33]. However, the difference in water intake according to gender is thought to require further research. In addition, it is necessary to consider the socioeconomic aspects to increase water intake, as the water intake was small at high income, education, and unemployed state.

In regard to toothbrushing among the oral health behaviors, water intake was high in all groups except for before dinner and before going to bed, and in all groups using oral health products except for the use of electric toothbrushes, in which water intake was high.

This indicates that oral health behavior is good in the group that consumes a lot of water per day, which is consistent with the study of Nam et al.

[19] that water intake behavior and oral care behavior are related.

However, there is no relationship between tongue brushing, number of brushing, brushing time, and use of auxiliary oral hygiene products among the oral health behaviors.

As a result, further research is deemed necessary. In addition, it was found that the group with high water intake received relatively simple treatments and preventive treatments, and the group with low water intake received more serious treatments.

It is thought that people receive a lot of treatment to maintain and promote oral health due to a lot of interest in health, including water intake.

In the oral health status, the group who consumed less water per day had high experience of toothache and perceived that they had a bad oral health status.

In addition, the group with high water intake had no speech problems, chewing problems and chewing inconvenience.

As such, it was confirmed that oral health and water intake are highly related as oral health problems were low in the group who consumes a lot of water per day.

In fact, the prevalence of periodontal disease increased by 1.018 times, the prevalence of dental caries increased by 1.032 times, and the experience of dental caries increased by 1.075 times each time a person drank one less cup of water per day.

Although this was analyzed by adjusting for the age, gender and oral health behavior affecting water intake and oral disease, the result was found to be significant, thereby confirming the importance of water intake for oral disease.

Since dental caries and periodontal disease are multifactorial diseases in which several factors act in combination, water intake cannot be limited as the cause of increasing or decreasing the likelihood of oral disease. However, it is thought that the recommended intake should be included in the dietary guidelines for preventing oral diseases in consideration of the importance of water intake. 


\section{Strengths and limitations}

The limitation of this study is that there are very few previous studies on water intake and oral health behaviors and state for all age groups, so it was somewhat difficult to compare and interpret the results of this study. There is also a limitation that it did not include systemic diseases and various lifestyles.

However, the relationship between water intake and oral health behavior and state in Korean people was analyzed through the representative data from the National Health and Nutrition Survey in order to motivate water intake.

Moreover, this study has its significance in providing data that can be used for direction setting when establishing policies or business plans for the recommendation of water intake at the national level. Research on the relationship between water intake and oral health is needed continuously, and follow-up studies to establish the standard of proper water intake in order to lower oral disease are considered to be necessary.

\section{Conclusions}

Based on the above results, people who consumed more water were at lower risk of dental caries and periodontal disease. Also, people who consumed more water were at lower risk of oral health status. Therefore, it is considered that the government's active promotion of water intake recommendations and policies should be prepared so that water intake can become a habit to improve oral health.

\section{Declarations}

\section{Ethics approval and consent to participate}

The National Health and Nutrition Survey is a government-designated statistics based on Article 17 of the Statistics Act (approval no. 117002). Informed consent was obtained from all individual participants included in the study. In the $5^{\text {th }}$ round, the $1^{\text {st }}$ year survey is $2010-02 C O N-21-C, 2^{\text {nd }}$ year survey, 201312 EXP-03-5C, and $3^{\text {rd }}$ year survey, 2012-01EXP-01-2C. In the $6^{\text {th }}$ round, the $1^{\text {st }}$ year survey is $2013-07 C O N-$ 03-4C and the $2^{\text {nd }}$ year survey is 2013-12EXP-03-5C. From the $3^{\text {rd }}$ year, it was conducted without deliberation by the Research Ethics Review Committee, as it corresponds to the research conducted by the State for public welfare directly pursuant to Subparagraph 1 of Article 2 (2). All methods were performed in accordance with the relevant guidelines and regulations.

\section{Consent for publication}

Not applicable.

\section{Availability of data and material}


The data sets generated and/or analyzed during the current study are not publicly available for reasons of personal and organizational integrity but are available from the corresponding author on reasonable request.

\section{Competing interests}

The authors claim no conflict of interest.

\section{Funding}

Not applicable.

\section{Authors' contributions}

Not applicable.

\section{Acknowledgements}

Not applicable.

\section{References}

1. Jéquier $E$, Constant $F$ : Water as an essential nutrient: the physiological basis of hydration. Eur J Clin Nutr 2010, 64(2):115-123. doi.org/10.1038/ ejcn.2009.111

2. Perrier $E$, Vergne $S$, Klein A, Poupin $M$, Rondeau P, Le Bellego $L$, et al: Hydration biomarkers in freeliving adults with different levels of habitual fluid consumption. Br J Nutr 2013, 109(9):1678-1687. org/10.1017/S0007114512003601

3. Lee JS: The effects of gender, obesity rate, nutrition knowledge and dietary attitude on the dietary self-efficacy on adolescents. Korean J Community Nutr 2003, 8(5):652-657.

4. W White, GH Nancollas: Quantitative study of enamel dissolution under conditions of controlled hydrodynamics. J dent Res 1997, 56(5):524-530. org/10.1177/00220345770560051301.

5. Verbalis JG: Disorders of body water homeostasis. Best Pract Res Clin Endocrinol Metab 2003, 17(4):471-503. org/10.1016/s1521-690x(03)00049-6

6. EFSA Panel on Dietetic Products, Nutrition, Allergies: Scientific opinion on dietary reference values for water. EFSA J 2010, 8(3):1459.

https://efsa.onlinelibrary.wiley.com/doi/epdf/10.2903/j.efsa.2010.1459

7. Hillyer M, Menon K, Singh R: The effects of dehydration on skill-based performance. Int J Sports Sci 2015, 5(3):99-107. org/10.5923/j.sports.20150503.02 
8. Daniels MC, Popkin BM: Impact of water intake on energy intake and weight status: a systematic review. Nutr Rev 2010, 68(9):505-521. org/10.1111/j.1753-4887.2010.00311.x.

9. Ruth JL, Wassner SJ: Body composition: salt and water. Pediatr Rev 2006, 27(5):181-187. org/10.1542/pir.27-5-181.

10. Committee on Nutrition and the Council on Sports Medicine and Fitness: Sports drinks and energy drinks for children and adolescents: are they appropriate? Pediatrics 2011, 127(6):1182-1189. org/10.1542/peds.2011-0965.

11. Sawka MN, Latzka WA, Matott RP, Montain SJ: Hydration effects on temperature regulation. Int J Sports Med 1998, 19(2):S108-110. org/10.1055/s-2007-971971.

12. Sawka MN, Cheuvront SN, Carter R: Human water needs. Nutr Rev 2005, 63(6 Pt 2):S30-S39. org/10.1111/j.1753-4887.2005.tb00152.x.

13. Raman A, Schoeller DA, Subar AF, Troiano RP, Schatzkin A, Harris T, et al: Water turnover in $\mathbf{4 5 8}$ American adults 40-79 yr of age. Am J Physiol Renal Physiol 2004, 286(2):F394-401. org/10.1152/ajprenal.00295.2003.

14. Food and Nutrition Board, Institute of Medicine: Dietary Reference Intakes for water, potassium, sodium, chloride, and sulfate. The national academies press, Washington D.C; 2005. p.1-616. org/10.17226/10925

15. Chidester J, Spangler A: Fluid intake in the institutionalized elderly. J Am Diet Assoc 1997, 97(1):2328. org/10.1016/S0002-8223(97)00011-4.

16. Feddes JJ, Emmanuel EJ, Zuidhoft MJ: Broiler performance, body weight variance, feed and water intake, and carcass quality at different stocking densities. Poultry Science 2002, 81(6):774-779. org/10.1093/ps/81.6.774

17. Ferreira-Pego C, Guelinckx I, Moreno LA, Kavouras SA, Gandy J, Martinez H, et al: Total fluid intake and its determinants: cross-sectional surveys among adults in 13 countries worldwide. Eur $J$ Nutr 2015, 54(2):35-43. org/10.1007/s00394-015-0943-9.

18. Armstrong-Esther C, Browne K, Armstrong-Esther D, Sander L: The institutionalized elderly: dry to the bone! Int J Nurs Stud 1996, 33(6):619-628. org/10.1016/s0020-7489(96)00023-5

19. Nam JY, Kim HJ, Park SM, Choi SH, Jeon HI, Kim MJ, Lee MK: The influence of water drinking on oral management behavior and bad breath in college students. AJMAHS 2017, 7(5):421-429. org/10.14257/ajmahs.2017.05.04.

20. Hong MH: Study on detection of oral bacteria in the saliva and risk factors of adults. JKAIS 2014, 15(9):5675-5682. org/10.5762/KAIS.2014.15.9.5675

21. Kang KH, Kim YK, Lee HS, Jin I: Analysis of gene expression in response to acid stress of streptococcus mutans Isolated from a Korean child. JKAIS 2009, 10(10):2990-2996. doi.org/10.5762/KAIS.2009.10.10.2990

22. Sofia DF, Marika B, Arthur CO: Streptococcus mutans, caries and simulation models. Nutriens 2010, 2(3):290-298. org/10.3390/nu2030290 
23. Park SN, Kook JK: Development of quantitative real-time PCR primers for detection of development prevotella intermedia. J. Oral Bio/ 2015, 40(4):205-210. doi.org/10.11620/IJOB.2015.40.4.205

24. Peck SY, Ku Y, Rhyu IC, Hahm BD, Han SB, Choi SM, Chung CP: The frequency of detecting prevotella intermedia and prevotella nigrescens in Korean adult periodontitis patients. J Periodontal Implant Sci 2000, 30(2):419-429. org/10.5051/jkape.2000.30.2.419

25. Joung HY, Choi Y, Choe HJ, Jung IH: A Convergence study of Water intake on relationship between Xerostomia, Halitosis, Oral microorganisms in the Elderly. Journal of the Korea Convergence Society 2019, 10(6):309-316. org/10.15207/JKCS.2019.10.6.309

26. Hong MH: Study on detection of oral bacteria in the saliva and risk factors of adults. JKAIS 2014, 15(9):5675-5682. doi.org/5762/KAIS.2014.15.9.5675

27. Paik IY, Yun DS, Suh SH, Roh HT: Effects of Different Fluid Replacements during Exercise in High Ambient Temperature on Inflammatory Cytokine Responses and Immune Function in Elite Athletes. KJSS 2011, 22(3):2076-2087. doi.org/24985/kjss.2011.22.3.2076

28. Popkin BM, D’Anci KE, Rosenberg IH: Water, hydration, and health. Nutr Rev 2010, 68(8):439-458. doi.org/1111/j.1753-4887.2010.00304.x

29. Benton D: Dehydration influences mood and cognition: a plausible hypothesis? Nutrients 2011, 3(5):555-573. doi.org/3390/nu3050555

30. Kant AK, Graubard BI, Atchison EA: Intakes of plain water, moisture in foods and beverages, and total water in the adult US population-nutritional, meal pattern, and body weight correlates: National Health and Nutrition Examination Surveys 1999-2006. Am J Clin Nutr 2009, 90(3):655-663. doi.org/3945/ajcn.2009.27749

31. Park S, Sherry B, O'Toole T, Huang Y: Factors associated with low drinking water intake among adolescents: the Florida Youth Physical Activity and Nutrition Survey, 2007. J Am Diet Assoc 2011, 111(8):1211-1217. doi.org/1016/j.jada.2011.05.006

32. Pintar KD, Waltner-Toews D, Charron D, Pollari F, Fazil A, McEwen SA, et al: Water consumption habits of a south-western Ontario community. J Water Health 2009, 7(2):276-292.

org/10.2166/wh.2009.038.

33. Stachenfeld NS: Hormonal changes during menopause and the impact on fluid regulation. Reprod Sci 2014, 21(5):555-561. org/10.1177/1933719113518992 